\title{
Isoleucine, an Essential Amino Acid, Induces the Expression of Human $\beta$ Defensin 2 through the Activation of the G-Protein Coupled Receptor-ERK Pathway in the Intestinal Epithelia
}

\author{
Youkou Konno" ${ }^{1}$, Toshifumi Ashida ${ }^{2}$, Yuhei Inaba ${ }^{1}$, Takahiro Ito ${ }^{1}$, Hiroki Tanabe ${ }^{1}$, Atsuo Maemoto ${ }^{2}$, \\ Tokiyoshi Ayabe $^{3}$, Yusuke Mizukami ${ }^{1}$, Mikihiro Fujiya ${ }^{1}$, Yutaka Kohgo ${ }^{1}$ \\ ${ }^{1}$ Division of Gastroenterology and Hematology/Oncology, Department of Medicine, Asahikawa Medical University, Asahikawa, \\ Japan; ${ }^{2}$ IBD Center, Sapporo Higashi Tokushukai Hospital, Sapporo, Japan; ${ }^{3}$ Innate Immunity Laboratory, Department of Cellular \\ Life Science, Faculty of Advanced Life Science, Hokkaido University, Sapporo, Japan. \\ Email: fjym@asahikawa-med.ac.jp
}

Received February $7^{\text {th }}, 2012$; revised March $7^{\text {th }}, 2012$; accepted March $16^{\text {th }}, 2012$

\begin{abstract}
Anti-microbial peptides are essential for the intestinal innate immunity that protects the intestinal epithelia from attacks by foreign pathogens. Human $\beta$-defensin (HBD) is one of the pivotal anti-microbial peptides that are expressed in the colonic epithelia. This study investigated the effect and the signaling mechanism of inducible $\beta$-defensin HBD2 by an essential amino acid, isoleucine (Ile) in colonic epithelial cells. Here we examined the expression level of HBD2 on induction of Ile in epithelial cells, and checked this pathway. HBD2 mRNA was induced by co-incubation with IL-1 $\alpha$ and Ile in Caco2 cells, but not by Ile alone. An inhibitor of either ERK or Gi, a subunit of G-proteins, reduced the induction of HBD2 mRNA by Ile. The treatment with Ile also increased the intracellular calcium ion concentration, thus suggesting that the GPCR and ERK signaling pathway mediate the effects of Ile. These results indicate that an essential amino acid, Ile, enhances the expression of an inducible $\beta$-defensin, namely HBD2, by IL-1 $\alpha$ through the activation of GPCRs and ERK signaling pathway. The administration of Ile may therefore represent a possible option to safely treat intestinal inflammation.
\end{abstract}

Keywords: Isoleucine; Human $\beta$-Defensin; G-Protein Coupled Receptor; Extracellular Signal-Regulated Kinases Pathway; Inflammatory Bowel Disease; Crohn's Disease

\section{Introduction}

The innate immunity system plays a significant role in inactivating pathogenic microbes which invade the host, particularly in the intestinal tract and skin, in which anti-microbial peptides are thought to be essential from attacks by bacteria, fungi and viruses [1]. Among the known anti-microbial peptides, both $\alpha$ and $\beta$ defensins, which belong to the defensin family, have been shown to play pivotal roles through their powerful anti-microbial activity [2]. We previously reported that $\alpha$-defensin was derived from small intestinal Paneth cells, which exhibit an anti-bacteriacidal function for pathogens such as Salmonella typhi [3]. The alterations in $\alpha$-defensin have since been considered to be associated with the etiology of various intestinal disorders such as cystic fibrosis [4] and Crohn's disease (CD) [5]. Conversely, $\beta$-defensin (HBD) is produced by the epithelial cells particularly in the bronchus and colon, which includes 6 isotypes,
HBD1 - 6 [6-10]. While HBD1 is constitutively expressed, HBD2 and 3 are inducible defensins. These HBDs are known to show an altered expression under inflammatory conditions due to attacks by bacteria-derived polysaccharides or other intestinal inflammations [11-14]. However, the precise mechanisms regarding how the inducible HBDs are associated with such inflammation remains to be elucidated. Inflammatory bowel disease (IBD) is a chronic inflammation in the digestive tract, which includes ulcerative colitis and Crohn's disease. Although the etiology of IBD remains unclear, some molecules that are involved in the innate immune system, such as nucleotide-binding oligomerization domain (NOD)2 [15], $\alpha$ and $\beta$ defensins [5,14], were altered in patients with IBD, particularly those with $\mathrm{CD}$. This suggests that the normalization of the function of such molecules, including $\beta$ defensin, may present a feasible option to treat $\mathrm{CD}$. The possibility that Ile enhanced 
the transcription of HBD2 mRNA has been demonstrated by a reporter assay using the promoter region of HBD2 [16], thus suggesting that one safe candidate to induce the expression of $\beta$ defensin is an essential amino acid, isoleucine (Ile). We herein propose that Ile induced HBD2 expression through the activation of the extracellular signal-regulated kinase (ERK) signaling pathway in intestinal epithelial cells only when a pro-inflammatory cytokine IL-1 $\alpha$ was also present. Furthermore, we show that such induction is mediated by the stimulation of G-protein coupled receptors (GPCRs) which are widely expressed in the digestive tract and act as a receptor for many chemical mediators and some amino acids.

\section{Materials and Methods}

\subsection{Cell Culture}

Human colonic epithelial Caco2 cells purchased from the ATCC (American Type Culture Collection, Manassas, VA) were grown in high-glucose Dulbecco's modified Eagle's medium (DMEM) supplemented with 20\% (vol/ vol) fetal bovine serum (FBS), $2 \mathrm{mM} \mathrm{L}$-glutamine, 25 $\mathrm{U} / \mathrm{mL}$ penicillin, $25 \mu \mathrm{g} / \mathrm{mL}$ streptomycin (all from Invitrogen/GIBCO, Grand Island, NY) and MEM non-essential amino acid solution (SIGMA, Hertfordshire, UK) in a humidified atmosphere of $5 \% \mathrm{CO}_{2}$. The cells were plated on 6 well plates or $35 \mathrm{~mm}$ dishes and then were allowed to differentiate for $10-14$ days before the experiments were performed.

\subsection{Real-Time PCR}

After the Caco2 cells were grown in serum-free media for 24 hours, various concentrations of Ile $(0,5,10,20$, $50,100,200$ and $500 \mathrm{ng} / \mathrm{ml})$ and/or IL- $1 \alpha(0,1,5,10,20$, $50 \mathrm{ng} / \mathrm{ml}$ ) were added to the cells in 6 well plates. For the analysis of their inhibitory effects, an ERK pathway inhibitor (PD98059; Cell signaling, Boston, USA) or a GPCRs inhibitor (Pertussis toxin (PTX); SIGMA) was added 2 hours or 16 hours, respectively, before the harvest of the cells. RNA was harvested from the Caco2 cells using Ultrespec TM (BIOTECX, Houston, TX, USA) and then was reverse-transcribed using the Oligo (dT) 20 primer (Invitrogen, Carlsbad, CA, USA) and Superscript II RT (Invitrogen). The HBD2 mRNA was amplified on a Light Cycler system (Roche) using specific primers (sense, 5-ggtataggcgatcctgttacetgc-3), antisense, 5-tcatggcttttgcagcatttgttc-3) in triplicate. The averaged mRNA expression of HBD2 was normalized to GAPDH expression (LightCycler-primer set Human GAPDH (search LC, Heidelberg, Germany)).

\subsection{Quantification of HBD2 Protein}

The cells were washed 3 times with PBS and treated with
Cell Lysis Buffer (Cell Signaling) with a Protease Inhibitor Cocktail Kit (PIERCE, Rockford, USA). Each lysate was centrifuged and the HBD2 protein in the supernatant was measured by a Human BD-2 ELISA Development Kit (PeproTech, Hamburg, Germany).

\subsection{Western Blotting}

After the incubation of $\mathrm{Caco} 2$ cells with inducers such as Ile for various times, the cells were treated with Cell Lysis Buffer (Cell Signaling) with a Protease Inhibitor Cocktail Kit (PIERCE, Rockford, USA) as described above. Forty $\mu \mathrm{g}$ of each sample was resolved by NuPAGE Bis-Tris polyacrylamid gel (12\%) (Invitrogen) and immediately transferred to a polyvinylidene difluoride (PVDF) membrane (Millipore) using 1X transfer buffer (25 mM Tris $\mathrm{pH} 8.8,192 \mathrm{mM}$ glycine with $15 \%$ [vol/vol] methanol). The PVDF membranes were incubated in PBS with $0.05 \%(\mathrm{vol} / \mathrm{vol})$ Tween 20 (T-PBS) containing 5\% (wt/ vol) milk for 1 hour at room temperature to block nonspecific binding. The blots were incubated overnight at $4^{\circ} \mathrm{C}$ with an anti-rabbit p44/p42 phospho- or total-ERK antibody (Cell Signaling) as the primary antibody. The blots were washed five times for 10 minutes each in T-PBS at room temperature, incubated for 60 minutes in HRP-conjugated rabbit anti-mouse IgG (Jackson Immunoresearch, West Grove, PA) in T-PBS, washed four times in TPBS, once in PBS, and developed using Western Lightning Chemiluminescence Reagent Plus (PerkinElmer, Massachusetts, USA).

\subsection{Determination of the Intracellular Calcium Ion Concentration}

Caco 2 cells were incubated with $5 \mu \mathrm{M}$ Fluo4 AM (Invitrogen) for 40 minutes, and then the cell images were obtained with a confocal laser capture microscope. The images were analyzed with an image-analytical software program (ZEN, 2007) to calculate the intensity of the fluorescence emitted from the cells.

\subsection{Statistical Analysis}

All measured values are presented as the means \pm standard deviation, and the statistical examinations were performed using Student's t-test. A p-value $<0.05$ was considered to be statistically significant.

\section{Results}

\subsection{HBD2 mRNA Is Induced in Caco2 Cells by Co-Incubation with IL-1 $\alpha$ and Ile}

The HBD mRNA expression was examined by real-time PCR. HBD2 mRNA was not detected after the treatment with any concentration of Ile alone. IL-1 $\alpha$ induced HBD2 
mRNA expression (Figure 1), and this induction occurred in a concentration-dependent manner (Figure 2(a)). The maximum induction of HBD2 mRNA was observed at 10 hours after the treatment (Figure 2(b)). Subsequently,

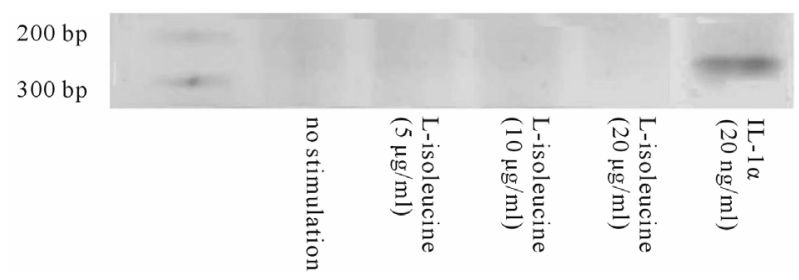

Figure 1. Induction of HBD2 mRNA by IL-1 $\alpha$. The products of RT-PCR were electrophoresed on an agarose gels. Treatment with $20 \mathrm{ng} / \mathrm{ml}$ IL-1 $\alpha$ alone, but not with Ile alone, induced HBD2 mRNA expression.

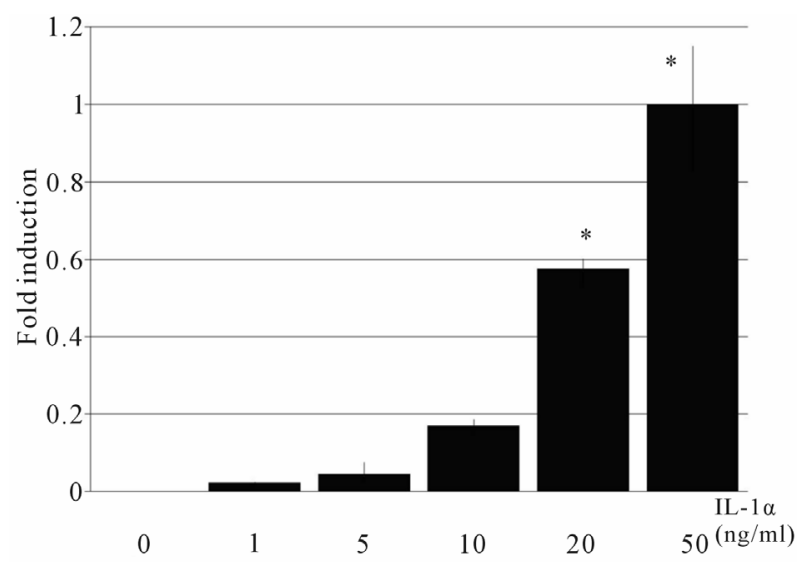

(a)

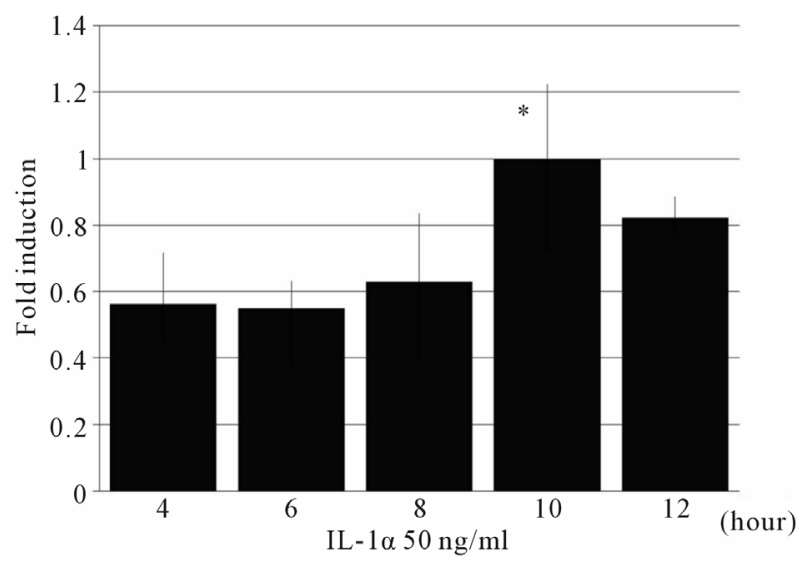

(b)

Figure 2. Concentration-dependent induction of HBD2 mRNA by IL-1 $\alpha$. Caco2 cells were incubated with various concentrations of IL- $1 \alpha$ for 10 hours. HBD2 mRNA was measured by real-time PCR. Il-1 $\alpha$ induced HBD2 expression in a concentration-dependent manner (a). The maximum induction of HBD2 mRNA was observed at 10 hours after the treatment (b). Each of the data represents an average \pm SD $(n=3)$. the effect of a co-incubation with IL- $1 \alpha$ and Ile on the expression of HBD mRNA was investigated. As shown in Figure 3, Ile significantly enhanced the IL- $1 \alpha$-induced expression of HBD2 mRNA, in a concentration-dependent manner. Ten $\mathrm{mg} / \mathrm{ml}$ of Ile was the best concentration for augmenting the induction of HBD2 mRNA. After treating cells using the same condition for 72 hours, the HBD2 protein was also increased in comparison to that in cells treated with IL- $1 \alpha$ alone (Figure 4).

\subsection{The ERK Signaling Pathway Mediates the Induction of HBD2 mRNA by Co-Incubation of Caco2 Cells with IL-1 $\alpha$ and Ile}

Because it has been proposed that the activation of the

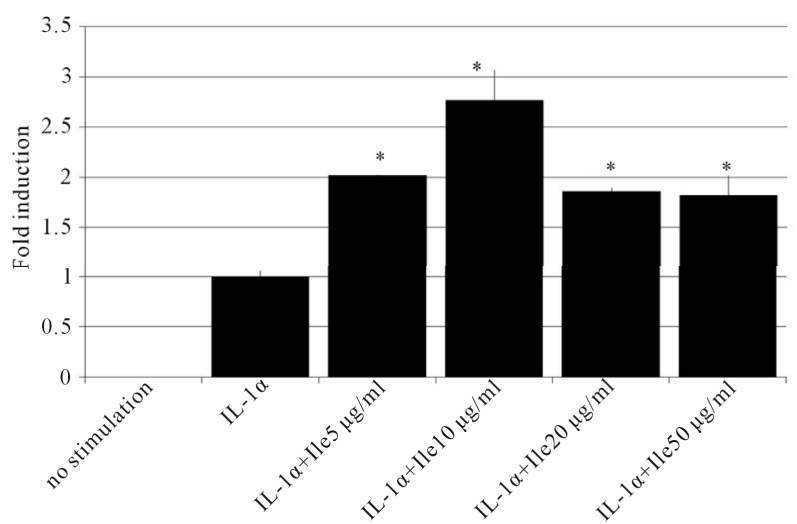

Figure 3. The effects of Ile on the induction of HBD2. Caco2 cells were incubated with various concentrations of Ile, and $50 \mathrm{ng} / \mathrm{ml}$ of IL-1 $\alpha$ for 10 hours. HBD2 mRNA was measured by real-time PCR. Ile, especially at $10 \mu \mathrm{g} / \mathrm{ml}$, enhanced the induction of HBD2 by IL-1 $\alpha$. The data are shown as the averages \pm SD $(n=3)$. ${ }^{*} p<0.05$.

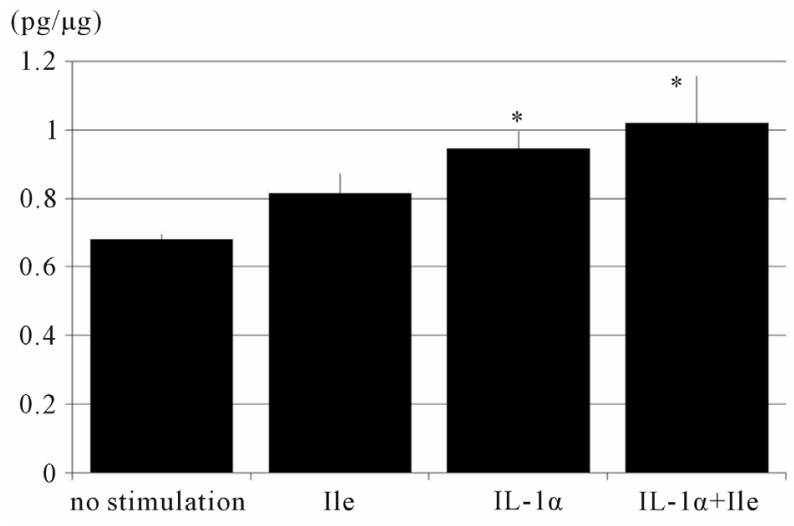

Figure 4. The measurement of $\mathrm{HBD} 2$ protein expression by ELISA. Caco2 cells were incubated with Ile and/or IL-1 $a$ for 72 hours. Then the cells were lysed, and the protein expression of HBD2 was measured by ELISA. IL-1 $\alpha$ or IL-1 $\alpha$ + Ile significantly induced HBD2 protein in Caco2 cells. The data are shown as the averages \pm SD $(n=3)$. " p $<0.05$. 
ERK signaling pathway mediated the increase in the expression of HBD2 [17], the phosphorylation of $\mathrm{p} 44 / 42$ ERK by IL- $1 \alpha$ or Ile was examined by a Western blot analysis. IL- $1 \alpha$ phosphorylated $\mathrm{p} 44 / 42$ beginning from 10 to 15 minutes after the start of treatment, and the effect was reversed within 30 minutes. In contrast, Ile phosphorylated p44/42 just 30 seconds after the initiation of treatment, and the effect was reversed within 10 minutes. Notably, a combination of IL- $1 \alpha$ and Ile extended the interval of the phosphorylation of $\mathrm{p} 44 / 42$ from 5 to 30 minutes, suggesting an additive effect of the combination (Figure 5). To confirm the involvement of the ERK signaling pathway in the induction of HBD2 mRNA expression, an ERK inhibitor (PD98059) was added to Caco 2 cells for 2 hours. The PD98059 treatment reduced the induction of HBD2 mRNA by the combination of IL-1 $\alpha$ and Ile (Figure 6), indicating the significant involvement of the ERK signaling pathway in this induction.

\subsection{GPCR Mediates the Effects of Ile on the Enhancement of IL-1 $\alpha$ Induced-HBD2 mRNA Expression}

While most amino acids are absorbed by specific transporters expressed at the cell membrane, some of them are known to act as ligands for GPCRs. For example, glutamic acid is absorbed into the epithelia, and is also bound to a taste receptor which is one of the GPCRs. Many types of GPCRs, such as taste receptor and GPR35, are expressed in the intestinal epithelia [18-20]. In addi-

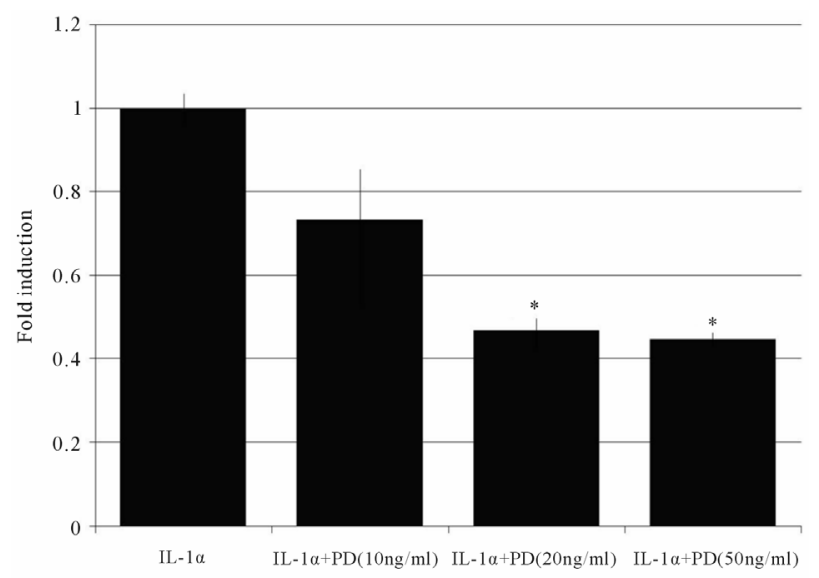

Figure 5. Changes in HBD2 mRNA expression in Caco2 cells treated with an inhibitor of the ERK signaling pathway. Caco2 cells were incubated with various concentrations of a MEK1-specific inhibitor, PD98059, for 2 hours. Then, the cells were treated with $50 \mathrm{ng} / \mathrm{ml}$ of IL-1 $\alpha$, and the HBD2 mRNA expression was measured by real-time PCR. PD98059 reduced the induction of HBD2 mRNA by IL-1 $\alpha$. The data are shown as the averages \pm SD $(n=3)$. * $\mathrm{p}<$ 0.05. PD $=$ PD98059.

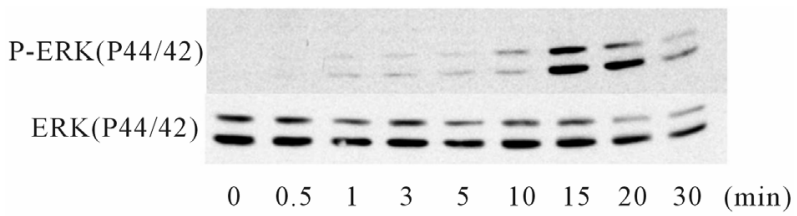

(a)

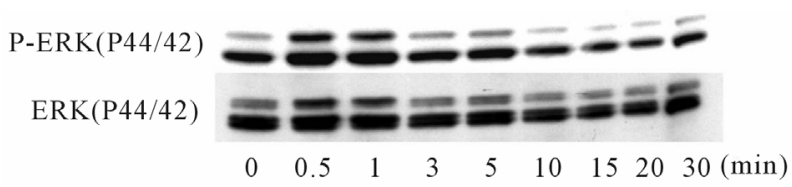

(b)

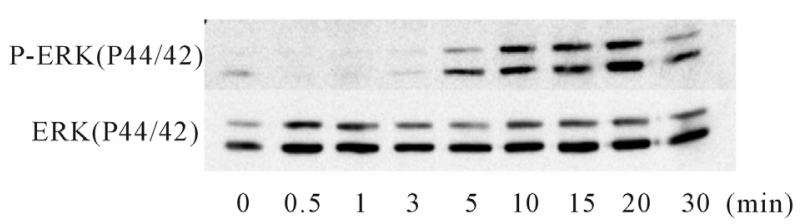

(c)

Figure 6. ERK1/2 phospholyration after treatment with Ile and/or IL-1 $\alpha$. ERK1//2 phospholyration was examined by a Western Blot analysis using an anti-rabbit p44/p42 phospho- or total-ERK antibody. A $50 \mathrm{ng} / \mathrm{ml}$ concentration of IL-1 $\alpha$ strongly phosphorylated ERK1/2 from 15 to 30 minutes (a). Conversely, $10 \mu \mathrm{g} / \mathrm{ml}$ of Ile phosphorylated ERK1/2 from 30 seconds to 10 minutes, earlier than that induced by IL-1 $\alpha$ (b). The Ile treatment extended the interval of the phosphorylation of ERK1/2 by IL-1 $\alpha$ (c).

tion, the functions of some GPCRs are associated with the expression of anti-microbial peptides in neutrophils and gingival cells $[21,22]$. Furthermore, an $\alpha$ subunit of the GPCRs, $\mathrm{Gi}$, is known to be involved in the activation of the ERK signaling pathway [23-29], suggesting a possibility that GPCRs are involved in the induction of HBD2 mRNA by Ile in the intestinal epithelia. To examine the influence of the GPCRs on the induction of HBD2 mRNA, Caco2 cells were incubated with an inhibitor of GPCRs, Pertussis toxin, for 16 hours before the treatment with IL- $1 \alpha$ and Ile. As shown in Figure 7, Pertussis toxin reduced the induction of HBD2 mRNA by the combination of IL- $1 \alpha$ and Ile in a concentration-dependent manner. Furthermore, Ile treatment increased the intracellular calcium ion concentration, which is a characteristic phenomenon that occurs after the binding between GPCRs and their ligands (Figure 8). These data strongly suggest that GPCRs are associated with the induction of HBD2 mRNA by the combination of IL- $1 \alpha$ and Ile.

\section{Discussion}

The present study demonstrated that an essential amino 


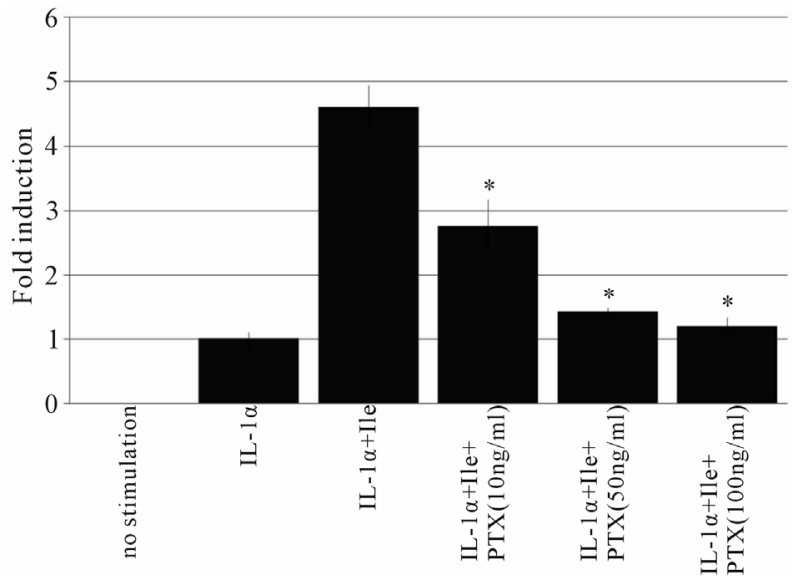

Figure 7. Changes in the expression of HBD2 mRNA by a specific inhibitor of the Gi subunit of G-proteins. Caco2 cells were treated with various concentrations of an inhibitor (Pertussis toxin; PTX) of Gi, which is a subunit of G-proteins for 16 hours. After adding both IL-1 $\alpha(50 \mathrm{ng} / \mathrm{ml})$ and Ile $(10 \mu \mathrm{g} / \mathrm{ml})$, the HBD2 mRNA expression was measured by real-time PCR. PTX reduced the induction of HBD2 mRNA by the combination of IL-1 $\alpha$ and Ile in a concentration-dependent manner. The data are shown as the averages \pm SD $(n=3) . ~ * p<0.05$.

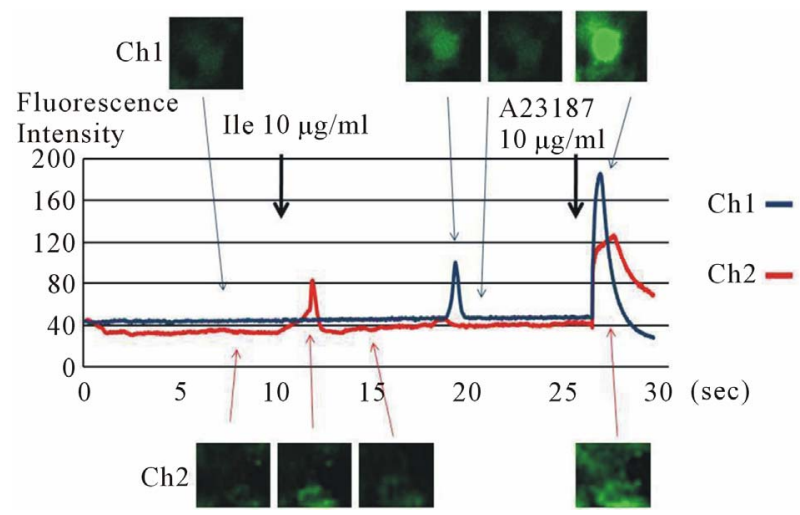

Figure 8. The increase in the intracellular calcium ion concentration by Ile treatment. The concentration of intracellular calcium ions was measured in Caco2 cells labeled with Fluo-4/AM. The emitted fluorescence was captured by confocal microscopy. After adding Ile, an increase of fluorescence intensity was observed in some cells, indicating that Ile augmented the concentration of intracellular calcium ions in the cells. The viability of the cells was confirmed by a $\mathrm{Ca}^{2+}$ ionophore, $\mathbf{A 2 3 1 8 7}$. The fluorescence intensities of two areas were measured by channels 1 (ch1) and 2 (ch2) by confocal microscopy. The $x$-axis shows the time course (seconds), and the y-axis shows the fluorescence intensities. The pictures of the upper and lower sides are the images of the areas captured by ch 1 and 2, respectively.

acid, Ile, augmented the expression of HBD2 induced by IL-1 $\alpha$ through the activation of the ERK signaling pathway, while Ile alone did not change the HBD2 expression. Furthermore, this Ile effect was reduced by an in- hibitor of GPCRs, Pertussis toxin, illustrating that GPCRs were also involved in the induction of HBD2 by the combination of IL-1 $\alpha$ and Ile. While it has been suggested that Ile induces the transcription of the promoter of the HBD2 gene [16], the current study is the first to confirm the effect of an essential amino acid, Ile, on the induction of HBD2, as well as to demonstrate the mechanism underlying this induction. It is worth noting that HBD2 could be induced by Ile only when IL-1 $\alpha$ a well-known pro-inflammatory cytokine, was also present. This suggests that Ile contributes to the induction of HBD2 only when the immune system is activated, such as occurs when the cells are under attack by foreign pathogens.

IL- $1 \alpha$ activates the ERK signaling pathway, which is known to be important for HBD2 expression [17]. The present study confirmed the effect of IL- $1 \alpha$ on the activation of the ERK signaling pathway, and in addition, we found that Ile treatment extended the interval of the activation of the ERK signaling pathway. Some amino acids, such as arginine, have been reported to activate ERK signaling, thus suggesting that the signaling pathway might be associated with the physiological function of amino acids [30]. Conversely, inhibitors of either p38 or JNK exerted no influence on the induction of HBD2 by Ile (data not shown), whereas an inhibitor of the ERK signaling pathway reduced the induction of HBD2. Accordingly, Ile enhanced the induction of HBD2 by IL- $1 \alpha$ by extending the activation interval of the ERK pathway.

Our data are the first to show that the induction of HDB2 by Ile was mediated by GPCRs, which are seventransmembrane domain receptors known to bind many ligands, such as chemical mediators and amino acids. GPCRs comprise a large protein family of transmembrane receptors that sense molecules outside the cell [31]. Once a ligand binds to a GPCR, the structure of the GPCR is changed, and a trimer-forming G protein is activated, leading to changes in the concentration of second messengers such as calcium ions and cAMP, and the subsequent activation of internal signal transduction pathways. A type of $\alpha$ subunit in the trimer of G proteins, the Gi subunit, is known to increase the intracellular concentration of the calcium ion through the activation of the $\beta \gamma$ subunit, and to stimulate the MAPK signaling pathway $[32,33]$. The present study proposed that HBD2 binds to GPCRs, activates the ERK signaling pathway through the activation of the Gi and $\beta \gamma$ subunits of the G-protein, and then induces HBD2 when cells are treated with both Ile and IL- $1 \alpha$. This is supported by the reduction of the effect of Ile on the induction of HBD2 when cells were treated with an inhibitor of the Gi subunit, Pertussis toxin. mGluR, GPR35 and the extracellular $\mathrm{Ca}^{2+}$ sensing receptor, which all have the ability to increase 
the intracellular calcium ion concentration and activate the ERK signaling pathway, might therefore be candidates for sensing Ile [17-19,34]. Further analysis with knockout models for such GPCRs is needed to determine the specific GPCR responsible for the effects of Ile.

It has been proposed that the defensins expression decrease in patients with CD $[5,14]$. Therefore, the induction of HBD2 by the administration of Ile is a possible option to treat $\mathrm{CD}$. We also confirmed that oral intake of Ile caused changes in the microflora in CD patients, possibly through the induction of HBD2 expression (data not shown). It was also reported that dexamethasone, a major drug used for the treatment of $\mathrm{CD}$, induced HBD2 in the presence of pro-inflammatory cytokines [35], and use of the elementary diet, which mainly consists of amino acids, relieved the activity of CD [36]. Furthermore, Ile treatment is regarded to exert few adverse effects, because it is a frequently consumed essential amino acid, and influences HBD2 expression only under inflammatory conditions. The expression of HBD1 mRNA has been shown to increase in HCT-116 cells after Ile treatment [37]. Taken together, the administration of Ile is thought to represent a feasible treatment for effectively and safely relieving CD. In summary, the present study is the first to demonstrate that an essential amino acid, Ile, enhances the expression of an inducible $\beta$-defensin, HBD2, by IL- $1 \alpha$ through the activation of GPCRs and the ERK signaling pathway. The administration of Ile is considered to affect HBD2 expression only under inflammatory conditions, thus suggesting that it would have few adverse effects in patients. The administration of Ile therefore represents a possible option to safely treat intestinal inflammation, including that due to CD.

\section{Acknowledgements}

This study was supported by a Grant-in-Aid for Scientific Research provided by the Ministry of Education, Culture, Sports, Science and Technology of Japan (Y.K., \#15390223 and \#19390194, T.I., \#20590733 and M.F., \#23590931) and by the Intractable Disease, the Health and Labour Sciences Research Grants from Ministry of Health, Labor and Welfare in Japan.

\section{REFERENCES}

[1] M. Zasloff, "Antimicrobial Peptides of Multicellular Organisms," Nature, Vol. 415, No. 6870, 2001, pp. 389-395. doi:10.1038/415389a

[2] N. H. Salzman, D. Ghosh, K. M. Huttner, Y. Paterson and C. L. Bevins, "Protection against Enteric Salmonellosis in Transgenic Mice Expressing a Human Intestinal Defensing," Nature, Vol. 422, No. 6931, 2003, pp. 522-526. doi:10.1038/nature 01520
[3] T. Ayabe, D. P. Satchell, C. L. Wilson, W. C. Parks, M. E. Selsted and A. J. Ouellette, "Secretion of Microbicidal Alpha-Defensins by Intestinal Paneth Cells in Response to Bacteria," Nature Immunology, Vol. 1, No. 2, 2000, pp. 113-118. doi: $10.1038 / 77783$

[4] A. J. Ouellette, "Paneth Cell Alpha-Defensins: Peptide Mediators of Innate Immunity in the Small Intestine," Springer Seminars in Immunopathology, Vol. 27, No. 2, 2005, pp. 133-146. doi:10.1007/s00281-005-0202-x

[5] J. Wehkamp, N. H. Salzman, E. Porter, S. Nuding, M. Weichenthal, R. E. Petras, B. Shen, E. Schaeffeler, M. Schwab, R. Linzmeier, R. W. Feathers, H. Chu, H. Lima Jr., K. Fellermann, T. Ganz, E. F. Stange and C. L. Bevins, "Reduced Paneth Cell Alpha-Defensins in Ileal Crohn's Disease," The Proceedings of the National Academy of Sciences USA, Vol. 102, No. 50, 2005, pp. 1812918134. doi: $10.1073 /$ pnas.0505256102

[6] M. N. Becker, G. Diamond, M. W. Verghese and S. H. Randell, "CD14-Dependent Lipopolysaccharide-Induced Beta-Defensin-2 Expression in Human Tracheobronchial Epithelium," The Journal of Biological Chemistry, Vol. 275, No. 38, 2000, pp. 29731-29736. doi:10.1074/jbc.M000184200

[7] C. Fulton, G. M. Anderson, M. Zasloff, R. Bull and A. G. Quinn, "Expression of Natural Peptide Antibiotics in Human Skin," Lancet, Vol. 350, 1997, pp. 1750-1751. doi:10.1016/S0140-6736(05)63574-X

[8] H. P. Jia, B. C. Schutte, A. Schudy, R. Linzmeier, J. M. Guthmiller, G. K. Johnson, B. F. Tack, J. P. Mitros, A. Rosenthal, T. Ganz and P. B. McCray Jr., "Discovery of New Human Beta-Defensins Using a Genomics-Based Approach," Gene, Vol. 263, No. 1-2, 2001, pp. 211-218. doi:10.1016/S0378-1119(00)00569-2

[9] P. K. Singh, H. P. Jia, K. Wiles, J. Hesselberth, L. Liu, B. A. Conway, E. P. Greenberg, E. V. Valore, M. J. Welsh, T. Ganz, B. F. Tack and P. B. McCray Jr., "Production of Beta-Defensins by Human airway Epithelia," The Proceedings of the National Academy of Sciences USA, Vol. 95, No. 25, 1998, pp. 14961-14966.

doi:10.1073/pnas.95.25.14961

[10] O. E. Sorensen, D. R. Thapa, A. Rosenthal, L. Liu, A. A. Roberts and T. Ganz, "Differential Regulation of BetaDefensin Expression in Human Skin by Microbial Stimuli," The Journal of Immunology, Vol. 74, No. 8, 2005, pp. 4870-4879.

[11] A. Y. Liu, D. Destoumieux, A. V. Wong, C. H. Park, E. V. Valore, L. Liu and T. Ganz, "Human-Defensin-2 Production in Keratinocytes Is Regulated by Interleukin-1, Bacteria, and the State of Differentiation," Journal of Investigative Dermatology, Vol. 118, 2002, pp. 275-281. doi:10.1046/j.0022-202x.2001.01651.x

[12] Y. Tsutsumi-Ishii and I. Nagaoka, "Modulation of Human $\beta$-Defensin-2 Transcription in Pulmonary Epithelial Cells by Lipopolysaccharide-Stimulated Mononuclear Phagocytes via Proinflammatory Cytokine Production," The Journal of Immunology, Vol. 170, 2003, p. 4226.

[13] J. Harder, J. Bartels, E. Christophers and J. M. Schroder, "Isolation and Characterization of Human $\beta$-Defensin-3, a 
Novel Human Inducible Peptide Antibiotic," The Journal of Biological Chemistry, Vol. 276, No. 51, 2001, pp. 5707-5713. doi:10.1074/jbc.M008557200

[14] J. Wehkamp, J. Harder, M. Weichenthal, O. Mueller, K. R. Herrlinger, K. Fellermann, J. M. Schroeder and E. F. Stange, "Inducible and Constitutive $\beta$-Defensins Are Differentially Expressed in Crohn's Disease and Ulcerative Colitis," Inflammatory Bowel Diseases, Vol. 9, No. 4, 2003, pp. 215-223.

doi:10.1097/00054725-200307000-00001

[15] J. P. Hugot, M. Chamaillard, H. Zouali, S. Lesage, J. P. Cézard, J. Belaiche, S. Almer, C. Tysk, C. A. O’Morain, M. Gassull, V. Binder, Y. Finkel, A. Cortot, R. Modigliani, P. Laurent-Puig, C. Gower-Rousseau, J. Macry, J. F. Colombel, M. Sahbatou and G. Thomas, "Association of NOD2 Leucine-Rich Repeat Variants with Susceptibility to Crohn's Disease," Nature, Vol. 411, No. 6837, 2001, pp. 599-603. doi:10.1038/35079107

[16] P. Fehlbaum, M. Rao, M. Zasloff and G. M. Anderson, "An Essential Amino Acid Induces Epithelial Beta-Defensin Expression," The Proceedings of the National Academy of Sciences USA, Vol. 97, No. 23, 2000, pp. 1272312728. doi: $10.1073 /$ pnas. 220424597

[17] S. K. Moon, H. Y. Lee, J. D. Li, M. Nagura, S. H. Kang, Y. M. Chun, F. H. Linthicum, T. Ganz, A. Andalibi and D. J. Lim, "Activation of a Src-Dependent Raf-MEK1/2ERK Signaling Pathway Is Required for IL-1a-Induced Upregulation of h-Defensin 2 in Human Middle Ear Epithelial Cells," Biochimica et Biophysica Acta, Vol. 1590, No. 1-3, 2002, pp. 41-51. doi:10.1016/S0167-4889(02)00196-9

[18] C. Bezencxon, J. le Coutre and S. Damak, "Taste-Signaling Proteins Are Coexpressed in Solitary Intestinal Epithelial Cells," Chemical Senses, Vol. 32, No. 1, 2007, pp. 41-49. doi:10.1093/chemse/bj1034

[19] S. Okumura, H. Baba, T. Kumada, K. Nanmoku, H. Nakajima, Y. Nakane, K. Hioki and K. Ikenaka, "Cloning of a G-Protein-Coupled Receptor That Shows an Activity to Transform NIH3T3 Cells and Is Expressed in Gastric Cancer Cells," Cancer Science, Vol. 95, No. 2, 2004, pp. 131-135. doi:10.1111/j.1349-7006.2004.tb03193.x

[20] B. F. O’Dowd, T. Nguyen, A. Marchese, R. Cheng, K. R. Lynch, H. H. Heng, L. F. Kolakowski Jr. and S. R. George, "Discovery of Three Novel G-Protein-Coupled Receptor Genes," Genomics, Vol. 47, No. 15, 1998, pp. 310-313. doi:10.1006/geno.1998.5095

[21] M. Wan, A. Sabirsh, A. Wetterholm, B. Agerberth and J. Z. Haeggstrom, "Leukotriene B4 Triggers Release of the Cathelicidin LL-37 from Human Neutrophils: Novel LipidPeptide Interactions in Innate Immune Responses," The FASEB Journal, Vol. 21, No. 11, 2007, pp. 2897-2905. doi:10.1096/fj.06-7974com

[22] H. Dommisch, W. O. Chung, M. G. Rohani, D. Williams, M. Rangarajan, M. A. Curtis and B. A. Dale, "ProteaseActivated Receptor 2 Mediates Human Beta-Defensin 2 and CC Chemokine Ligand 20 mRNA Expression in Response to Proteases Secreted by Porphyromonas gin- givalis," Infection and Immunity, Vol. 75, No. 9. 2007, pp.
4326- 4333. doi:10.1128/IAI.00455-07

[23] L. R. Howe and C. J. Marshall, "Lysophosphatidic Acid Stimulates Mitogen-Activated Protein Kinase Activation via a G-Protein-Coupled Pathway Requiring p21ras and p74raf-1," The Journal of Biological Chemistry, Vol. 268, No. 28, 1993, pp. 20717-20720.

[24] P. L. Hordijk, I. Verlaan, E. J. van Corven and W. H. Moolenaar, "Protein Tyrosine Phosphorylation Induced by Lysophosphatidic Acid in Rat-1 Fibroblasts. Evidence that Phosphorylation of Map Kinase Is Mediated by the Gi-p21ras Pathway," The Journal of Biological Chemistry, Vol. 269, No. 1, 1994, pp. 645-651.

[25] V. J. LaMorte, E. D. Kennedy, L. R. Collins, D. Goldstein, A. T. Harootunian, J. H. Brown and J. R. Feramisco, "A Requirement for Ras Protein Function in ThrombinStimulated Mitogenesis in Astrocytoma Cells," The Journal of Biological Chemistry, Vol. 268, No. 26, 1993, pp. 19411-19415.

[26] J. E. Duff, B. C. Berk and M. A. Corson, "Angiotensin II Stimulates the pp44 and pp42 Mitogen-Activated Protein Kinases in Cultured Rat Aortic Smooth Muscle Cells," Biochemical and Biophysical Research Communications, Vol. 188, No. 1, 1992, pp. 257-264. doi:10.1016/0006-291X(92)92378-B

[27] Y. Ishida, Y. Kawahara, T. Tsuda, M. Koide and M. Yokoyama, "Involvement of MAP Kinase Activators in Angiotensin II-Induced Activation of MAP Kinases in Cultured Vascular Smooth Muscle Cells," FEBS Letters, Vol. 310, No. 1, 1992, pp. 41-45. doi:10.1016/0014-5793(92)81142-9

[28] B. E. Hawes, T. van Biesen, W. J. Koch, L. M. Luttrell and R. J. Lefkowitz, "Distinct Pathways of $\mathrm{G}_{\mathrm{i}}{ }^{-}$and $\mathrm{G}_{\mathrm{q}}$ Mediated Mitogen-Activated Protein Kinase Activation," The Journal of Biological Chemistry, Vol. 270, 1995, pp. 17148-17153. doi:10.1074/jbc.270.29.17148

[29] T. van Biesen, B. E. Hawes, D. K. Luttrell, K. M. Krueger, K. Touhara, E. Porfiri, M. Sakaue, L. M. Luttrell, and R. J. Lefkowitz, "Receptor-Tyrosine-Kinase- and G Beta Gamma-Mediated MAP Kinase Activation by a Common Signalling Pathway," Nature, Vol. 376, No. 6543, 1995, pp. 781-784. doi:10.1038/376781a0

[30] V. Mieulet, L. Yan, C. Choisy, K. Sully, J. Procter, A. Kouroumalis, S. Krywawych, M. Pende, S. C. Ley, C. Moinard and R. F. Lamb, "TPL-2-Mediated Activation of MAPK Downstream of TLR4 Signaling Is Coupled to Arginine Availability," Science Signaling, Vol. 3, No. 135, 2010, p. ra61. doi:10.1126/scisignal.2000934

[31] S. K. Moon, H. Y. Lee, J. D. Li, M. Nagura, S. H. Kang, Y. M. Chun, F. H. Linthicum, T. Ganz, A. Andalibi and D. J. Lim, "Activation of a Src-Dependent Raf-MEK1/2ERK Signaling Pathway Is Required for IL-1a-Induced Upregulation of h-Defensin 2 in Human Middle Ear Epithelial Cells," Biochimica et Biophysica Acta, Vol. 1590, No. 1-3, 2002, pp. 41-51. doi:10.1016/S0167-4889(02)00196-9

[32] N. Wettschureck and S. Offermanns, "Mammalian G Proteins and Their Cell Type Specific Functions," Physiological Reviews, Vol. 85, No. 4, 2005, pp. 1159-1204. 
doi:10.1152/physrev.00003.2005

[33] Y. Chen-Izu, R. P. Xiao, L.T. Izu, H. Cheng, M. Kuschel, H. Spurgeon and E. G. Lakatta, "G(i)-Dependent Localization of Beta(2)-Adrenergic Receptor Signaling to LType $\mathrm{Ca}(2+)$ Channels," Biophysical Journal, Vol. 79, No. 5, 2000, pp. 2547-2556. doi:10.1016/S0006-3495(00)76495-2

[34] H. J. Lee, H. C. Mun, N. C. Lewis, M. F. Crouch, E. L. Culverston, R. S. Mason and A. D. Conigrave, "Allosteric Activation of the Extracellular $\mathrm{Ca}^{2+}$-Sensing Receptor by L-Amino Acids Enhances ERK1/2 Phosphorylation," Biochemical Journal, Vol. 404, Part 1, 2007, pp. 141-149. doi:10.1042/BJ20061826

[35] T. Witthöft, C. S. Pilz, K. Fellermann, M. Nitschke, E. F.
Stange and D. Ludwig, "Enhanced Human $\beta$-Defensin-2 (hBD-2) Expression by Corticosteroids Is Independent of NF- $\kappa \mathrm{B}$ in Colonic Epithelial Cells $\left(\mathrm{CaCO}_{2}\right)$," Digestive Diseases and Sciences, Vol. 50, No. 7, 2005, pp. 12521259.

[36] M. H. Giaffer, G. North and C. D. Holdsworth, "Controlled Trial of Polymeric versus Elemental Diet in Treatment of Active Crohn's Disease," Lancet, Vol. 335, No. 8693, 1990, pp. 816-819. doi:10.1016/0140-6736(90)90936-Y

[37] H. Sherman, N. Chapnik and O. Froy, "Albumin and Amino Acids Upregulate the Expression of Human BetaDefensin 1," Molecular Immunology, Vol. 43, No. 10, 2006, pp. 1617-1623. doi:10.1016/j.molimm.2005.09.013 